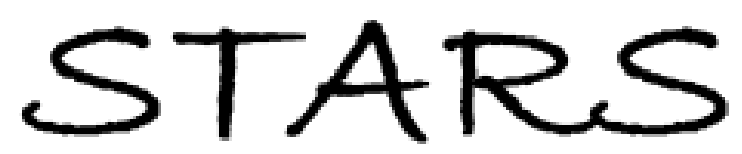

University of Central Florida

STARS

Faculty Scholarship and Creative Works

$9-1-2020$

\title{
Satisfaction vs Experienced Utility: Current Issues and Opportunities
}

\author{
Maksim Godovykh \\ University of Central Florida, maksim.godovykh@ucf.edu
}

Asli D. A. Tasci

University of Central Florida, asli.tasci@ucf.edu

Part of the Hospitality Administration and Management Commons, and the Tourism and Travel Commons

Find similar works at: https://stars.library.ucf.edu/ucfscholar

University of Central Florida Libraries http://library.ucf.edu

This Paper is brought to you for free and open access by STARS. It has been accepted for inclusion in Faculty Scholarship and Creative Works by an authorized administrator of STARS. For more information, please contact STARS@ucf.edu.

\section{Original Citation}

Godovykh, M., \& Tasci, A. D. A. (2020). Satisfaction vs experienced utility: current issues and opportunities. Current Issues in Tourism, 23(18), 2273-2282. https://doi.org/10.1080/ 13683500.2020 .1769573

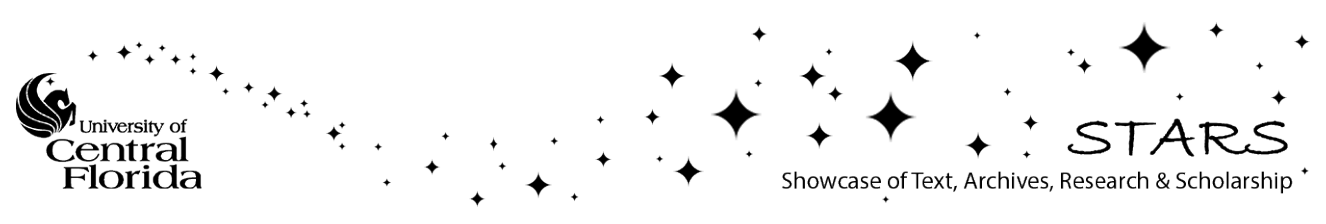




\title{
Satisfaction vs experienced utility: Current issues and opportunities
}

\author{
Maksim Godovykh* and Asli D.A. Tasci \\ Rosen College of Hospitality Management, University of Central Florida, Orlando, USA
}

\begin{abstract}
Satisfaction is one of the most studied constructs in many fields, including tourism. As an important marketing metric, satisfaction is typically measured with self-reported retrospective evaluations of travel experience. However, the memory-based approaches have numerous limitations related to social desirability, availability heuristics, previous knowledge, mood at the time of answering questions and do not reflect the moment-by-moment nature of visitor experience. The shortcomings and limitations of self-reported retrospective evaluations could be eliminated by introducing pre-visit, on-site, and post-visit instant components of experienced utility as measures of visitor experience. The experienced utility allows eliminating the majority of self-report biases, capturing the affective components of visitor experience, analyzing relationships between anticipation, experienced, and remembered utilities, and applying emerging moment-based research techniques. Therefore, this manuscript proposes a measurable definition of experienced utility and appropriate measures to assess visitor experience.
\end{abstract}

Keywords: experienced utility; satisfaction; anticipation; instant utility; remembered utility

\section{To cite this article:}

Godovykh, M., \& Tasci, A. D. A. (2020). Satisfaction vs experienced utility: Current issues and opportunities. Current Issues in Tourism, 23(18), 2273-2282.

https://doi.org/10.1080/13683500.2020.1769573 


\section{Introduction}

The prevalent research practice in measuring satisfaction as an outcome of consumption is the use of self-reported retrospective evaluations (Hill \& Alexander, 2017). However, these memory-based approaches have numerous limitations and do not reflect the moment-by-moment nature of tourism experience that extends from anticipation to remembering (Cohen, Prayag, \& Moital, 2014). Tourism activities are highly experiential taking place over an extended time period (Mannell \& Iso-Ahola, 1987; Chang, 2018), which demands measurement both in real time and retrospectively for capturing the true nature of consumption. However, self-reported retrospective measures have the limitations because they 1) are biased by social desirability, availability heuristics, and mood while answering questions (Holtgraves, 2017; Nazlan, Tanford, \& Montgomery, 2018);2) typically do not capture changes in affective dimensions of customer experience (Prayag, Hosany, Muskat, \& Del Chiappa, 2017); and 3) do not reflect the whole spectrum of customer evaluations (Bianchi, 2016). Conversely, the experienced utility may be superior in 1) capturing the affective components of visitor experience, 2) eliminating the majority of self-report biases, 3) investigating the relationships between temporal components of visitor experience with different antecedents and outcomes, and 4) applying emerging multidisciplinary moment-based research techniques. Thus, this manuscript puts forward an argument that the experienced utility construct may be a better measure of visitor experience in tourism research and analyzes its advantages in comparison with the widely-used satisfaction concept.

\section{Satisfaction and its measures}

Satisfaction is one of the most commonly used constructs in explaining visitor experience in tourism. Oliver (2014) described satisfaction as a consumer's overall fulfillment response, which 
includes a state of under-fulfillment and over-fulfillment resulting from the trade-off between pre-consumption and post-consumption attitudes. Expectancy disconfirmation theory is the most widely accepted theoretical framework for studying customer satisfaction (Oliver, 1980), while researchers also suggest that equity theory (Adams, 1963), attribution theory (Kelley, 1967), contrast theory (Dawes, Singer, \& Lemons, 1972), assimilation theory (Anderson, 1973), and other frameworks could be applied in satisfaction research (e.g., Oh, 1999; Pizam, Shapoval, \& Ellis, 2016; Prayag, Hosany, Muskat, \& Del Chiappa, 2017).

The literature differentiates between transaction-specific satisfaction, as evaluation of single episodes of interaction with a product or service (Lee, Backman, \& Backman, 2018), as opposed to the cumulative formulations of satisfaction as a function of multiple interactions with a product or service (Ekinci, Dawes, \& Massey, 2008). While the transaction-specific approach has an advantage of capturing satisfaction immediately after each product or service interaction (Danaher \& Matson, 1994), it does not reflect the overall experience (Oliver, 1980; Bitner \& Hubbert, 1994; Ladeira, Santini, Araujo, \& Sampaio, 2016). The traditional instruments of satisfaction research are self-report scales with several product or service attributes (Vavra, 1997; Hill \& Alexander, 2017), measuring satisfaction as a self-reported retrospective evaluation of the previous experience.

\section{Limitations of satisfaction}

A considerable amount of literature describes satisfaction as a cognitive state, resulting from a comparison between previous reference points from expectations and subjective experience with the performance of the product or service (De Rojas \& Camarero, 2008). However, using selfreported retrospective measures to assess satisfaction with previous experiences has numerous limitations. Respondents tend to provide socially desirable responses that are not always 
reflecting their real feelings (Fischer \& Fick, 1993; Holtgraves, 2017). People's answers are biased by availability heuristic as they make judgments based on things that come to their mind first (Nazlan, Tanford, \& Montgomery, 2018). Survey responses could also be dependent on previous knowledge (Ross, 1989) and the mood while answering questions (Eich \& Metcalfe, 1989). Several studies also describe situations when participants lack the introspective ability to accurately assess themselves (Silvia \& Phillips, 2011). Furthermore, the affective components of satisfaction are dynamic and time-dependent (Lee \& Kyle 2012; Kim \& Fesenmaier, 2015; Prayag, Hosany, Muskat, \& Del Chiappa, 2017) and therefore, should be captured in real time. Some of these limitations of self-report methods might be eliminated by applying more objective measures that are not influenced by opinions, momentary moods, or perspectives of respondents.

Another issue is that one-time measured satisfaction does not capture the temporal dimensions of customer experience, especially a trip experience, which consists of pre-visit, onsite, and post-visit components (Cohen, Prayag, \& Moital, 2014). Pre-visit anticipation significantly influences future experience (Dixon, Victorino, Kwortnik, \& Verma, 2017). Additionally, customer experience lasts much longer than the actual duration of the trip because of memories and post-visit retrospective evaluations (Pine \& Gilmore, 2011). Post-visit evaluations also contribute to the total amount of pleasure received from the experience (Morewedge, 2015) and have significant effects on subsequent behavior (Tung, Lin, Qiu Zhang, \& Zhao, 2017; Parks \& Santos, 2017). Therefore, experience should be measured at different time points, and the impacts of particular travel activities should be measured by comparing experience before, during, and after the event.

Furthermore, the satisfaction construct does not reflect the whole spectrum of customer evaluations. As a result, researchers need to investigate additional concepts such as satisfaction 
and consumer delight at the positive end of the satisfaction spectrum (Rust \& Oliver, 2000;

Berman, 2005, Kim, Vogt, \& Knutson, 2015) and dissatisfaction (Zairi, 2000; Sanchez-Garcia \& Currás-Pérez, 2011; Xu \& Li, 2016), as well as disappointment and regret (Zeelenberg, Van Dijk, Manstead, \& der Pligt, 1998; Zeelenberg \& Pieters, 2004) at the negative end. The bipolar nature of satisfaction was previously acknowledged in tourism and hospitality research (i.e., Alegre, \& Garau, 2010; Bianchi, 2016); however, research with positive, neutral, and negative values of satisfaction is lacking in the literature.

\section{Experienced utility and its measures}

Those shortcomings and limitations of satisfaction could be eliminated by introducing the experienced utility construct as a measure of visitor experience. The concept of utility has different meanings in different contexts. The economic utility function represents consumer preferences in a choice set of goods and services with values assigned to each alternative (Fishburn, 1970; Bordley \& LiCalzi, 2000; Kontek \& Lewandowski, 2017). On the other hand, the experienced utility is the amount of pleasure or displeasure evoked from experience (Kahneman, Wakker, \& Sarin, 1997), which is a moment-based variable that can be measured instantly and directly.

The basic unit of experienced utility is the instant utility, or "a measure of hedonic and affective experience, which can be derived from immediate reports of current subjective experience or psychological indices" (Kahneman, Wakker, \& Sarin, 1997, p. 376). The instant utility is influenced by sensory experiences, feelings, imaginations, and thoughts before, during, and after the visit (Figure 1). The anticipation utility is described as the process of deriving positive or negative feelings from savoring future experiences, which allows repeatedly experiencing emotional impacts of future events before they actually happen (Loewenstein \& 
Elster, 1992). The experienced utility is the impact of instant utilities evoked from the actual experience during the visit, while remembered utility is inferred from the recollection of autobiographical memories and can evoke both negative and positive instant utilities (Morewedge, 2015; Phillipe, Koestner, Lecours, Beaulieu-Pelletier, \& Bois, 2011). The total utility or the integral of all moments of instant utility is mentioned as a concept in the literature (Kahneman, 2003); however, a standard method to calculate the relative contribution of pre-, during-, and post-visit components to the total utility does not exist (Morewedge, 2015) and might be too difficult to achieve, undermining the principle of scientific parsimony.

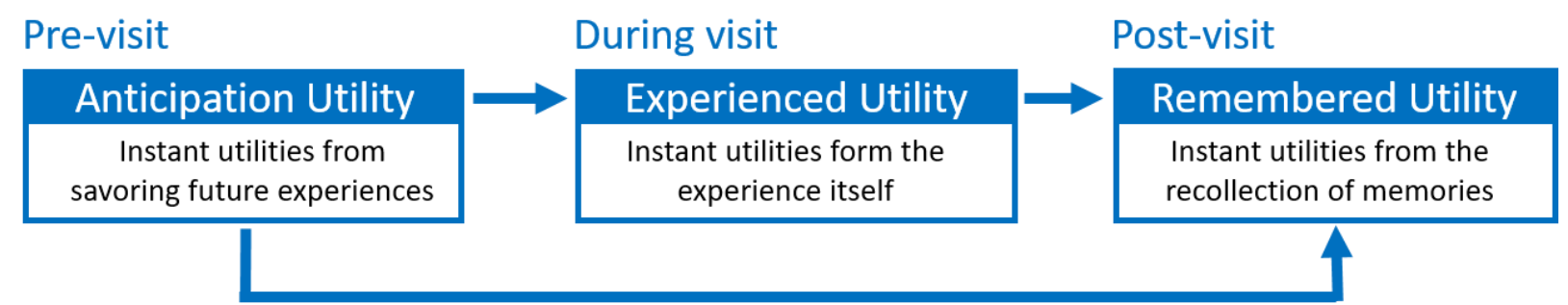

Figure 1. Pre-, during-, and post-visit components of visitor experience.

As an application of experienced utility, Carmon and Kahneman (1996) explored the experienced utility of queuing by analyzing people's real-time responses and found that a longer line that ended with a fast-moving segment had better retrospective evaluations than a shorter queue without any positive experience at the end. In another study, Baucells and Bellezza (2016) outlined temporal profiles of instant utility before, during, and after events by introducing the anticipation-event-recall model based on three key psychological elements: adaptation, conceptual consumptions, and time distance. In tourism context, Chang (2018) applied the experienced utility concept to explore consumers' post-visit evaluations of tangible and intangible hospitality and tourism products. In a similar vein, Barnes, Mattsson, and Sorensen 
(2016) investigated remembered utility of a safari park visitors and concluded that longer-term remembered experiences have stronger effects on customers' revisit intentions.

The momentary nature of visitor experience demands to apply moment-based methodology. One method of measuring instant utility before, during, and after the trip is the Experience Sampling Method (Csikszentmihayi \& Larson, 1987), which involves asking participants to report their actions and feelings on random occasions of time throughout the experience. Quinlan Cutler, Doherty, and Carmichael (2018) suggest that Experience Sampling Method (ESM) could be used to capture real-time tourist experience, while modern technologies allow using smartphones, developing spatial ESM procedures, and applying psychophysiological techniques. Experience sampling would also help to analyze the impacts of particular travel activities by comparing visitors' experienced utility across different phases of experience (i.e., before, during, and after an event or trip) as well as across different experiences. However, the experience sampling technique is also based on people's responses and might have self-report limitations. A more effective method of capturing instantaneous experienced utility is based on recording responses of the human autonomic nervous system when respondents cannot control their psychophysiological responses (Stern, Ray, \& Quigley, 2001).

Recent studies in cognitive science suggest that people's attitudes and behaviors are often influenced by automatic processes and human decisions could be made outside of conscious awareness (Martin \& Morich, 2011; Bargh et al., 2012; Newell \& Shanks, 2014; Li, Scott, \& Walters, 2015). Kihlstrom (1987) provided several examples of mental processes that lie beyond conscious awareness but also influence human experience, thoughts, and actions. Bargh and Chartrand (1999) advanced the idea that even highly complex cognitive activities can exist outside of conscious understanding. Thus, psychophysiological and neuroimaging research 
techniques (e.g., electrodermal activity, electrocardiography, pupillometry, electroencephalography, etc.) that do not depend on the people's capability to understand and describe their emotions (Larsen \& Fredrickson, 1999) could help to capture the unconscious components of consumer experiences.

Different experiences trigger different activation patterns of sympathetic and parasympathetic branches of the human autonomic nervous system (Kreibig, 2010), which can be useful in measuring experienced utilities of tourist activities. The sympathetic system prepares the body to react to stress and refers to mobilizing and activation, while the parasympathetic system is associated with dampening and relaxation (Ekman, Levenson, \& Friesen, 1983). Emotional arousal as an indicator of experience intensity can be measured by using electrodermal activity, electrocardiography, and pupillometry (Stern, Ray, \& Quingley, 2001), while the valence of experienced utility can be captured by applying methods such as facial electromyography, electroencephalography.

Electrodermal activity (EDA) reflects changes in the electrical properties of the skin caused by interaction between respondents' emotional states and environmental events and can be a proper indicator of respondents' arousal or intensity of experience (Koelsch, 2005; Kim \& Fesenmaier, 2015; Li, Walters, Packer, \& Scott, 2018). Electrocardiography (ECG), including measures of heart rate, blood pressure, and heart rate variability can be considered as an objective measure of instant experienced utility since they reflect activity of the autonomous nervous system and provide information about the current emotional state of respondents (Appelhans \& Luecken, 2006; Mauss \& Robinson, 2009; Selvaraj, Murugappan, Wan, \& Yaacob, 2013; Li, Walters, Packer, \& Scott, 2018). The literature describes pupillometry as another method of reflecting emotional arousal, which could be related to the intensity of travel 
experience from moment to moment (Breadly, Miccoli, Escrig, \& Lang, 2008; Eckstein, GuerraCarrillo, Singley, \& Bunge, 2017).

Elecromyography (EMG) of facial muscles makes it possible to analyze the valence of experienced utility (Tassinary, Cacioppo, \& Vanman, 2007; Li, Walters, Packer, \& Scott, 2018). The contraction of the corrugator muscle, which is related to frowning, is associated with negative experience, which zygotomaticus muscle that draws the mouth angle reflects positive emotional states (Tan et al., 2012). Electroencephalography (EEG), or electrophysiological monitoring of electrical activity of the brain, might be seen as one more promising technique in measuring instant components of experienced utility (Luck, 2015; Moyle, Moyle, Bec, \& Scott, 2019). Applying EEG in comparison with other behavior, self-report, and psychophysiological methods will potentially lead to higher temporal resolution of the results (Menon et al., 1997; Luck, 2015), while modern portable EEG systems make it possible to use them in real tourism settings (Mohsen, Zekry, \& Elshazly, 2016; Bobby, Lavanya, Jayashree, \& Viswanath, 2017).

Psychophysiological responses are not controlled by people and can eliminate the limitations of self-report and behavioral measures. Paulus (2002) suggested that psychophysiological measures can overcome respondents' cognitive and social desirability biases. Larsen and Fredrickson (1999) asserted that psychophysiological techniques do not rely on respondents' ability to verbalize their emotional responses. Moreover, psychophysiological recordings provide experienced utility moment-by-moment (Wilhelm \& Grossman, 2010) before, during, and after the experience. Li, Walters, Packer, and Scott (2018) applied several psychophysiological measures of skin conductance and facial electromyography in tourism settings and confirmed the ability of psychophysiological techniques to capture moment-bymoment responses to tourism advertising. 


\section{Advantages of experienced utility}

Experienced utility with its moment-by-moment measures may be a better concept to capture the multidimensional nature of experiential consumption in tourism for several reasons. First, different techniques of measuring experienced utility could help to avoid self-report and memory biases while measuring evaluations of all contiguous episodes without distracting people from normal activities. Psychophysiological data from the autonomic nervous system may help to capture unconscious components of consumer experience by using the moment-by-moment instant utility on a ratio scale with a neutral point. Measures and techniques in Table 1 are provided as a guide for future research.

\section{Table 1}

Techniques and measures of experienced utility.

\begin{tabular}{|c|c|c|}
\hline Measures & Dimensions & Techniques \\
\hline $\begin{array}{l}\text { Systematic self-reports at } \\
\text { random time intervals }\end{array}$ & $\begin{array}{l}\text { Discrete emotions, } \\
\text { intensity, valence, feelings }\end{array}$ & $\begin{array}{l}\text { Experience sampling method } \\
\text { (ESM) }\end{array}$ \\
\hline Skin conductance & Intensity & Electrodermal activity (EDA) \\
\hline Facial muscle responses & Valence & Electromyography (EMG) \\
\hline $\begin{array}{l}\text { Electrical activity of the } \\
\text { heartbeat }\end{array}$ & Intensity & Electrocardiography (ECG) \\
\hline Pupil size and reactivity & Intensity, cognitive efforts & Pupillometry \\
\hline $\begin{array}{l}\text { Electrophysiological } \\
\text { response of the brain }\end{array}$ & $\begin{array}{l}\text { Valence, intensity, } \\
\text { neurocognitive processes }\end{array}$ & Electroencephalography (EEG) \\
\hline
\end{tabular}

Source: Authors

Second, introducing experienced utility enables capturing the whole spectrum of outcomes of positive and negative emotions evoked by the product or service, including satisfaction, dissatisfaction, regret, delight, and other currently applied constructs. For instance, customer delight at the positive end of satisfaction spectrum (Oliver, Rust, \& Varki, 1997) will be related to a high positive level of experienced utility, while dissatisfaction, regret, and 
disappointment at the negative end of the spectrum (Zeelenberg \& Pieters, 2004) will be presented as a negative experienced utility.

Third, differentiating several components of experienced utility as anticipation utility, experienced utility, and remembered utility allows analyzing relationships between different components of utility and their relative effects on customer outcomes. It is possible that in contrast with satisfaction, different components of experienced utility are influenced by different antecedents (i.e., expectations, motivation, familiarity, etc.) and have different effects on various outcomes. For example, studies show the influence of anticipation utility on customer well-being (Kahneman, 1999; Morewedge, 2015), while remembered utility is associated with revisit intentions (Barnes, Mattsson, \& Sorensen, 2016).

Fourth, the proposed moment-based measurements help to detect unconscious affective components of visitor experience, which may contribute to important human-oriented outcomes. The previous literature proposed the effects of positive experience on well-being (Uysal, Sirgy, Woo, \& Kim, 2016), health (Van Cappellen, Rice, Catalino, \& Fredrickson, 2018), and transformation (Reisinger, 2013). However, these relationships have not been empirically investigated, and the literature on well-being and transformation outcomes still remains conceptual.

Furthermore, researchers may cross-fertilize tourism theories with those in other fields by integrating experienced utility with theories related to time discounting (Matta, Concalves, \& Bizarro, 2012), duration neglect (Kahneman, Fredrickson, Schreiber, \& Redelmeier, 1993), violations of dominance (Mellers, Weiss, \& Birnbaum, 1992), and other insights from psychology and behavioral economics. The previously observed effects of time, memories, and 
anticipation could be applied to different temporal components of experienced utility, and thus, foster fruitful opportunities for tourism research.

Despite the obvious advantages of applying the experienced utility construct in tourism research, it is necessary to take into account several limitations related to the expensiveness of the moment-based methodology and the complexity of data analysis and interpreting results. Additionally, the literature suggests that psychophysiological responses could depend on different external (temperature, humidity, luminance) and internal (medications, age, movements) factors (Picard, Fedor, \& Ayzenberg, 2016). Therefore, researchers need to control additional environmental and confounding factors while conducting laboratory and field experiments with moment-based techniques.

\section{Conclusion}

This article suggests that experienced utility may be a better measure of visitor experience than the widely applied satisfaction in tourism research. This concept with moment-based measures can be applied in exploring consumer outcomes from a variety of service products including tourism, hospitality, healthcare, and public service. These products have pre-visit, on-site, and post-visit temporal components, with potentially different antecedents and outcomes.

Future research on experienced utility will lead to a better understanding of tourists' loyalty as well as other important customer-oriented outcomes of tourism activities such as wellbeing, health, and transformation, which are mostly based on the affective components of customer experience. Further applications of experienced utility in tourism, hospitality, healthcare, and public service are needed to assess the reliability and validity of each measure, 
and investigate the relationships between anticipated utility, experienced utility, remembered utility, as well as their antecedents and outcomes.

\section{References}

Adams, J. S. (1963). Towards an understanding of inequity. The Journal of Abnormal and Social Psychology, 67(5), 422-436.

Alegre, J., \& Garau, J. (2010). Tourist satisfaction and dissatisfaction. Annals of Tourism Research, 37(1), 52-73.

Anderson, R. E. (1973). Consumer dissatisfaction: The effect of disconfirmed expectancy on perceived product performance. Journal of Marketing Research, 10(1), 38-44.

Appelhans, B. M., \& Luecken, L. J. (2006). Heart rate variability as an index of regulated emotional responding. Review of General Psychology, 10(3), 229-240.

Bargh, J. A., \& Chartrand, T. L. (1999). The unbearable automaticity of being. American Psychologist, 54(7), 462.

Barnes, S. J., Mattsson, J., \& Sorensen, F. (2016). Remembered experiences and revisit intentions: A longitudinal study of safari park visitors. Tourism Management, 57, 286294.

Baucells, M., \& Bellezza, S. (2016). Temporal profiles of instant utility during anticipation, event, and recall. Management Science, 63(3), 729-748.

Bianchi, C. (2016). Solo holiday travellers: Motivators and drivers of satisfaction and dissatisfaction. International Journal of Tourism Research, 18(2), 197-208. 
Bitner, M. J., \& Hubbert, A. R. (1994). Encounter satisfaction versus overall satisfaction versus quality. Service Quality: New Directions in Theory and Practice, 34(2), 72-94.

Bobby, M. J. S., Lavanya, B., Jayashree, M., \& Viswanath, V. (2017). EEG Radio Telemetry. International Journal of Emerging Trends in Science and Technology, 4(6), 5221-5227.

Bollas, C. (1995). Cracking up: The work of unconscious experience. New York, NY: Psychology Press.

Bordley, R., \& LiCalzi, M. (2000). Decision analysis using targets instead of utility functions. Decisions in Economics and Finance, 23(1), 53-74.

Bradley, M. M., Miccoli, L., Escrig, M. A., \& Lang, P. J. (2008). The pupil as a measure of emotional arousal and autonomic activation. Psychophysiology, 45(4), 602-607.

Brent Ritchie, J. R., Wing Sun Tung, V., \& JB Ritchie, R. (2011). Tourism experience management research: Emergence, evolution and future directions. International Journal of Contemporary Hospitality Management, 23(4), 419-438.

Carmon, Z., \& Kahneman, D. (1996). The experienced utility of queuing: Real time affect and retrospective evaluations of simulated queues. Duke University: Durham, NC, USA.

Chang, S. (2018). Experience economy in hospitality and tourism: Gain and loss values for service and experience. Tourism Management, 64, 55-63.

Cohen, S. A., Prayag, G., \& Moital, M. (2014). Consumer behaviour in tourism: Concepts, influences and opportunities. Current Issues in Tourism, 17(10), 872-909.

Csikszentmihalyi, M., \& Larson, R. (2014). Validity and reliability of the experience-sampling method. In M. Csikszentmihalyi (Ed.), Flow and the foundations of positive psychology (pp. 35-54). New York, NY: Springer. 
Danaher, P. J., \& Mattsson, J. (1994). Cumulative encounter satisfaction in the hotel conference process. International Journal of Service Industry Management, 5(4), 69-80.

Dawes, R. M., Singer, D., \& Lemons, F. (1972). An experimental analysis of the contrast effect and its implications for intergroup communication and the indirect assessment of attitude. Journal of Personality and Social Psychology, 21(3), 281-295.

De Rojas, C., \& Camarero, C. (2008). Visitors' experience, mood and satisfaction in a heritage context: Evidence from an interpretation center. Tourism Management, 29(3), 525-537.

Diener, E., Wirtz, D., \& Oishi, S. (2001). End effects of rated life quality: The James Dean effect. Psychological Science, 12(2), 124-128.

Dixon, M. J., Victorino, L., Kwortnik, R. J., \& Verma, R. (2017). Surprise, anticipation, and sequence effects in the design of experiential services. Production and Operations Management, 26(5), 945-960.

Do, A. M., Rupert, A. V., \& Wolford, G. (2008). Evaluations of pleasurable experiences: The peak-end rule. Psychonomic Bulletin \& Review, 15(1), 96-98.

Eckstein, M. K., Guerra-Carrillo, B., Singley, A. T. M., \& Bunge, S. A. (2017). Beyond eye gaze: What else can eyetracking reveal about cognition and cognitive development?. Developmental Cognitive Neuroscience, 25, 69-91.

Eich, E., \& Metcalfe, J. (1989). Mood dependent memory for internal versus external events. Journal of Experimental Psychology: Learning, Memory, and Cognition, 15(3), 443.

Ekinci, Y., Dawes, P. L., \& Massey, G. R. (2008). An extended model of the antecedents and consequences of consumer satisfaction for hospitality services. European Journal of Marketing, 42(1/2), 35-68. 
Ekman, P., Levenson, R. W., \& Friesen, W. V. (1983). Autonomic nervous system activity distinguishes among emotions. Science, 221(4616), 1208-1210.

Fan, X., Miller, B. C., Park, K. E., Winward, B. W., Christensen, M., Grotevant, H. D., \& Tai, R. H. (2006). An exploratory study about inaccuracy and invalidity in adolescent self-report surveys. Field Methods, 18(3), 223-244.

Fischer, D. G., \& Fick, C. (1993). Measuring social desirability: Short forms of the MarloweCrowne social desirability scale. Educational and Psychological measurement, 53(2), 417-424.

Fishburn, P. C. (1970). Utility theory for decision making (No. RAC-R-105). Research analysis corp McLean VA.

Geng, X., Chen, Z., Lam, W., \& Zheng, Q. (2013). Hedonic evaluation over short and long retention intervals: The mechanism of the peak-end rule. Journal of Behavioral Decision Making, 26(3), 225-236.

Hill, N., \& Alexander, J. (2017). The handbook of customer satisfaction and loyalty measurement. New York, NY: Routledge.

Holtgraves, T. (2017). Social desirability and the interpretation of uncertainty terms in self-report questions. Applied Cognitive Psychology, 31(6), 623-631.

Kahneman, D. (2003). Experienced utility and objective happiness: A moment-based approach. In I. Brocas \& J. D. Carrillo (Eds.), The psychology of economic decisions (pp. 187-208). New York, NY: Oxfrod University Press.

Kahneman, D., Fredrickson, B. L., Schreiber, C. A., \& Redelmeier, D. A. (1993). When more pain is preferred to less: Adding a better end. Psychological Science, 4(6), 401-405. 
Kahneman, D., Krueger, A. B., Schkade, D. A., Schwarz, N., \& Stone, A. A. (2004). A survey method for characterizing daily life experience: The day reconstruction method. Science, 306(5702), 1776-1780.

Kahneman, D., Wakker, P. P., \& Sarin, R. (1997). Back to Bentham? Explorations of experienced utility. The Quarterly Journal of Economics, 112(2), 375-406.

Kelley, H. H. (1973). The processes of causal attribution. American psychologist, 28(2), $107-$ 128.

Kihlstrom, J. F. (1987). The cognitive unconscious. Science, 237(4821), 1445-1452.

Kim, J., \& Fesenmaier, D. R. (2015). Measuring emotions in real time: Implications for tourism experience design. Journal of Travel Research, 54(4), 419-429.

Kim, M., Vogt, C. A., \& Knutson, B. J. (2015). Relationships among customer satisfaction, delight, and loyalty in the hospitality industry. Journal of Hospitality \& Tourism Research, 39(2), 170-197.

Koelsch, S. (2005). Investigating emotion with music. Annals of the New York Academy of Sciences, 1060(1), 412-418.

Kontek, K., \& Lewandowski, M. (2017). Range-dependent utility. Management Science, 64(6), 2812-2832.

Kreibig, S. D. (2010). Autonomic nervous system activity in emotion: A review. Biological Psychology, 84(3), 394-421.

Ladeira, W. J., Santini, F. D. O., Araujo, C. F., \& Sampaio, C. H. (2016). A meta-analysis of the antecedents and consequences of satisfaction in tourism and hospitality. Journal of Hospitality Marketing \& Management, 25(8), 975-1009. 
Ladhari, R. (2009). Service quality, emotional satisfaction, and behavioural intentions: A study in the hotel industry. Managing Service Quality: An International Journal, 19(3), 308331.

Larsen, R. J., \& Fredrickson, B. L. (1999). Measurement issues in emotion research. In D. Kahneman, E. Diener, \& N. Schwarz (Eds.), Well-being: The Foundations of Hedonic Psychology (40-60). New York, NY: Russel Sage Foundation.

Lee, J. C., Backman, K. F., \& Backman, S. J. (2018). An Investigation of the Relationships Among Service Quality, Transaction-Specific Satisfaction, and Overall Satisfaction in Predicting Golfers' Repurchase Intention. Event Management, 22(5), 849-864.

Lee, J., \& Kyle, G. T. (2012). Recollection consistency of festival consumption emotions. Journal of Travel Research, 51(2), 178-190.

Li, S., Scott, N., \& Walters, G. (2015). Current and potential methods for measuring emotion in tourism experiences: A review. Current Issues in Tourism, 18(9), 805-827.

Li, S., Walters, G., Packer, J., \& Scott, N. (2018). Using skin conductance and facial electromyography to measure emotional responses to tourism advertising. Current Issues in Tourism, 21(15), 1761-1783.

Loewenstein, G., \& Elster, J. (1992). Utility from memory and anticipation. In G. Loewenstein \& J. Elster (Eds.), Choice over time (pp. 213-234). New York, NY: Russel Sage Foundation.

Luck, S. J. (2014). An introduction to the event-related potential technique. Cambridge, MA: MIT Press.

Mannell, R. C., \& Iso-Ahola, S. E. (1987). Psychological nature of leisure and tourism experience. Annals of Tourism Research, 14(3), 314-331. 
Martin, N., \& Morich, K. (2011). Unconscious mental processes in consumer choice: Toward a new model of consumer behavior. Journal of Brand Management, 18(7), 483-505.

Matta, A. D., Gonçalves, F. L., \& Bizarro, L. (2012). Delay discounting: Concepts and measures. Psychology \& Neuroscience, 5(2), 135.

Matzler, K., \& Sauerwein, E. (2002). The factor structure of customer satisfaction: An empirical test of the importance grid and the penalty-reward-contrast analysis. International Journal of Service Industry Management, 13(4), 314-332.

Mauss, I. B., \& Robinson, M. D. (2009). Measures of emotion: A review. Cognition and Emotion, 23(2), 209-237.

Mellers, B., Weiss, R., \& Birnbaum, M. (1992). Violations of dominance in pricing judgments. Journal of Risk and Uncertainty, 5(1), 73-90.

Meng, F., Tepanon, Y., \& Uysal, M. (2008). Measuring tourist satisfaction by attribute and motivation: The case of a nature-based resort. Journal of Vacation Marketing, 14(1), 4156.

Menon, V., Ford, J. M., Lim, K. O., Glover, G. H., \& Pfefferbaum, A. (1997). Combined eventrelated fMRI and EEG evidence for temporal — parietal cortex activation during target detection. Neuroreport, 8(14), 3029-3037.

Mohsen, S., Zekry, A., \& Elshazly, A. (2016). Development of a portable DAQ-based Electroencephalogram System. International Journal of Computer Applications, 142(5), 33-38.

Morewedge, C. K. (2015). Utility: Anticipated, experienced, and remembered. In G., Keren \& G. Wu (Eds.), Wiley-Blackwell handbook of judgment and decision making (pp. 295330). Hoboken, NJ: John Wiley \& Sons. 
Moyle, B. D., Moyle, C. L., Bec, A., \& Scott, N. (2019). The next frontier in tourism emotion research. Current Issues in Tourism, 22(12), 1393-1399.

Nazlan, N. H., Tanford, S., \& Montgomery, R. (2018). The effect of availability heuristics in online consumer reviews. Journal of Consumer Behaviour, 17(5), 449-460.

Oh, H., \& Parks, S. C. (1996). Customer satisfaction and service quality: a critical review of the literature and research implications for the hospitality industry. Hospitality Research Journal, 20(3), 35-64.

Oliver, R. L. (1980). A cognitive model of the antecedents and consequences of satisfaction decisions. Journal of Marketing Research, 17(4), 460-469.

Oliver, R. L. (2014). Satisfaction: A behavioral perspective on the consumer: A behavioral perspective on the consumer. New York, NY: Routledge.

Park, S., \& Santos, C. A. (2017). Exploring the tourist experience: A sequential approach. Journal of Travel Research, 56(1), 16-27.

Philippe, F. L., Koestner, R., Lecours, S., Beaulieu-Pelletier, G., \& Bois, K. (2011). The role of autobiographical memory networks in the experience of negative emotions: How our remembered past elicits our current feelings. Emotion, 11(6), 1279-1290.

Picard, R. W., Fedor, S., \& Ayzenberg, Y. (2016). Multiple arousal theory and daily-life electrodermal activity asymmetry. Emotion Review, 8(1), 62-75.

Pizam, A., Shapoval, V., \& Ellis, T. (2016). Customer satisfaction and its measurement in hospitality enterprises: a revisit and update. International Journal of Contemporary Hospitality Management, 28(1), 2-35. 
Prayag, G., Hosany, S., Muskat, B., \& Del Chiappa, G. (2017). Understanding the relationships between tourists' emotional experiences, perceived overall image, satisfaction, and intention to recommend. Journal of Travel Research, 56(1), 41-54.

Quinlan Cutler, S., Doherty, S., \& Carmichael, B. (2018). The experience sampling method: Examining its use and potential in tourist experience research. Current Issues in Tourism, 21(9), 1052-1074.

Redelmeier, D. A., \& Kahneman, D. (1996). Patients' memories of painful medical treatments: Real-time and retrospective evaluations of two minimally invasive procedures. Pain, 66(1), 3-8.

Reisinger, Y. (2013). Transformational tourism: Tourist perspectives. Oxfordshire, UK: CABI. Ross, M. (1989). Relation of implicit theories to the construction of personal histories. Psychological Review, 96(2), 341-357.

Rust, R. T., \& Oliver, R. L. (2000). Should we delight the customer?. Journal of the Academy of Marketing Science, 28(1), 86.

Sánchez-García, I., \& Currás-Pérez, R. (2011). Effects of dissatisfaction in tourist services: The role of anger and regret. Tourism Management, 32(6), 1397-1406.

Selvaraj, J., Murugappan, M., Wan, K., \& Yaacob, S. (2013). Classification of emotional states from electrocardiogram signals: a non-linear approach based on hurst. Biomedical Engineering Online, 12(1), 1-18.

Silvia, P. J., \& Phillips, A. G. (2011). Evaluating self-reflection and insight as self-conscious traits. Personality and Individual Differences, 50(2), 234-237.

Stern, R. M., Ray, W. J., \& Quigley, K. S. (2001). Psychophysiological recording. New York, NY: Oxford University Press. 
Stern, R. M., Stern, R. M., Ray, W. J., \& Quigley, K. S. (2001). Psychophysiological recording. New York, NY: Oxford University Press.

Tan, J. W., Walter, S., Scheck, A., Hrabal, D., Hoffmann, H., Kessler, H., \& Traue, H. C. (2012). Repeatability of facial electromyography (EMG) activity over corrugator supercilii and zygomaticus major on differentiating various emotions. Journal of Ambient Intelligence and Humanized Computing, 3(1), 3-10

Tassinary, L. G., Cacioppo, J. T., \& Vanman, E. J. (2007). The skeletomotor system: Surface electromyography. In J. T. Cacioppo, L. G. Tassinary, \& G. G. Berntson (Eds.), Handbook of psychophysiology (p. 267-299). New York, NY: Cambridge University Press.

Tung, V. W. S., Lin, P., Qiu Zhang, H., \& Zhao, A. (2017). A framework of memory management and tourism experiences. Journal of Travel \& Tourism Marketing, 34(7), 853-866.

Uysal, M., Sirgy, M. J., Woo, E., \& Kim, H. L. (2016). Quality of life (QOL) and well-being research in tourism. Tourism Management, 53, 244-261.

Van Cappellen, P., Rice, E. L., Catalino, L. I., \& Fredrickson, B. L. (2018). Positive affective processes underlie positive health behaviour change. Psychology \& Health, 33(1), 77-97.

Vavra, T. G. (1997). Improving your measurement of customer satisfaction: A guide to creating, conducting, analyzing, and reporting customer satisfaction measurement programs. Milwaukee, WI: ASQ quality press.

Xu, X., \& Li, Y. (2016). The antecedents of customer satisfaction and dissatisfaction toward various types of hotels: A text mining approach. International Journal of Hospitality Management, 55, 57-69. 
Zairi, M. (2000). Managing customer dissatisfaction through effective complaints management systems. The TQM Journal, 12(5), 331-337.

Zeelenberg, M., \& Pieters, R. (2004). Beyond valence in customer dissatisfaction: A review and new findings on behavioral responses to regret and disappointment in failed services. Journal of Business Research, 57(4), 445-455.

Zeelenberg, M., Van Dijk, W. W., SR Manstead, A., \& der Pligt, J. (1998). The experience of regret and disappointment. Cognition \& Emotion, 12(2), 221-230. 
